\title{
Effect of disturbance on biomass, production and carbon dynamics in moist tropical forest of eastern Nepal
}

\author{
Tilak Prasad Gautam ${ }^{*}$ and Tej Narayan Mandal ${ }^{2}$
}

\begin{abstract}
Background: Forest biomass is helpful to assess its productivity and carbon (C) sequestration capacity. Several disturbance activities in tropical forests have reduced the biomass and net primary production (NPP) leading to climate change. Therefore, an accurate estimation of forest biomass and C cycling in context of disturbances is required for implementing REDD (Reducing Emissions from Deforestation and Forest Degradation) policy.

Methods: Biomass and NPP of trees and shrubs were estimated by using allometric equations while herbaceous biomass was estimated by harvest method. Fine root biomass was determined from soil monolith. The $\mathrm{C}$ stock in vegetation was calculated by multiplying $C$ concentration to dry weight.

Results: Total stand biomass (Mg.ha ${ }^{-1}$ ) in undisturbed forest stand (US) was 960.4 while in disturbed forest

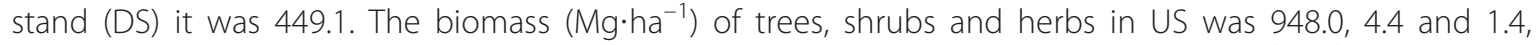

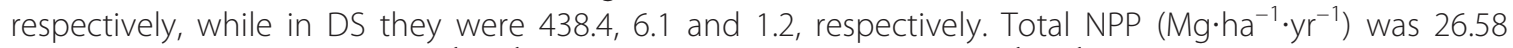
(equivalent to $12.26 \mathrm{Mg} \mathrm{C} \cdot \mathrm{ha}^{-1} \cdot \mathrm{yr}^{-1}$ ) in US and $14.91\left(6.88 \mathrm{MgC} \cdot \mathrm{ha}^{-1} \cdot \mathrm{yr}^{-1}\right)$ in DS. Total C input into soil

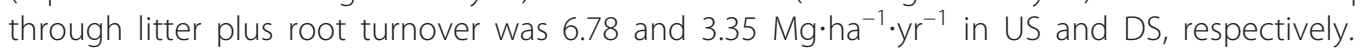

Conclusions: Several disturbance activities resulted in the significant loss in stand biomass (53\%), NPP (44\%), and C sequestration capacity of tropical forest in eastern Nepal. The net uptake of carbon by the vegetation is far greater than that returned to the soil by the turnover of fine root and litter. Therefore, both stands of present forest act as carbon accumulating systems. Moreover, disturbance reflects higher $\mathrm{C}$ emissions which can be reduced by better management.
\end{abstract}

Keywords: Tropical forest, Disturbance, Biomass, Production, Carbon cycling, Nepal

\section{Background}

Tropical forests play an important role in the global C cycle. They contain about $55 \%$ of global forest C (Pan et al. 2011) and account for $34 \%$ of terrestrial gross primary production (Beer et al. 2010). Carbon is stored in forests mainly in biomass and soils. The $\mathrm{C}$ dynamics of a forest reflects environmental conditions such as climate, soil, structure, nutrient availability and disturbance (Chave et al. 2001). Forest disturbances often lead to the changes in species composition, structure, stand biomass, productivity

\footnotetext{
* Correspondence: tilakg024@gmail.com

'Department of Botany, Mahendra Morang Adarsha Multiple Campus,

Tribhuvan University, Biratnagar, Nepal

Full list of author information is available at the end of the article
}

and $\mathrm{C}$ cycling. Therefore, a small disruption in tropical forests might result in a significant change in the global C cycle.

Biomass and production are important parameters for understanding the functioning of a forest ecosystem. Studies on biomass help to assess the effect of disturbances on productivity, $\mathrm{C}$ dynamics, nutrient cycling and stability of forest stands. Primary production is usually regulated by the availability of nutrients. Decomposed fine roots and aboveground litter are the sources of nutrients in the soil. The contribution of fine roots in the $\mathrm{C}$ and nutrients input to soil is equivalent or even higher to that from leaf litter in tropical moist forests (Roderstein et al. 2005). 
Precise quantification of forest biomass, production, and $\mathrm{C}$ stock demands the careful estimation of both the aboveground and belowground aspects. Despite this requirement, most of the past studies in tropical forests are found to be limited to analyzing the aboveground systems (Chave et al. 2008; Djomo et al. 2011; Malhi et al. 2011; Doughty et al. 2013; Ngo et al. 2013; Girardin et al. 2014; Malhi et al. 2014) and only a few studies concern to the belowground aspects (Ibrahima et al. 2010; Powers and Perez-Aviles 2013; Noguchi et al. 2014).

In Nepal, only few studies have been conducted regarding the biomass, production, and $\mathrm{C}$ sequestration in tropical forests (Mandal 1999; Baral et al. 2009). More information is required to understand the structure and functioning of the forests. Present study was designed in tropical forest of eastern Nepal with the following specific objectives: a) to estimate the biomass and production of herb, shrub and tree species; b) to find out the effect of disturbance on biomass, production and $\mathrm{C}$ dynamics.

\section{Methods}

\section{Study area}

The study was conducted in a Sal (Shorea robusta) dominated moist tropical forest of Sunsari District, eastern Nepal (latitude $26^{\circ} 41^{\prime} \mathrm{N}$ to $26^{\circ} 50^{\prime} \mathrm{N}$ and longitude $87^{\circ} 09^{\prime} \mathrm{E}$ to $87^{\circ} 21^{\prime} \mathrm{E}$ ), within the altitude range of 220 to $370 \mathrm{~m}$ above msl (Fig. 1). The forest lies in the catchment area of Koshi River, one of the largest rivers in Nepal. The total area occupied by the forest is 11394 ha.

The central part (core area) of the forest is relatively undisturbed, while the peripheral part is affected by disturbance activities as removal of timber, livestock grazing, fuel-wood and litter collection, tree lopping, removal of poles for house-hold constructions and forest fires. These disturbances have caused deforestation, forest fragmentation and degradation and subsequent invasion of exotic species like Mikania micrantha, Lantana camara, and Chromolaena odorata, which adversely affect the native plant diversity in the forest.

The climate is tropical and monsoon type with three distinct seasons: dry and warm summer (March to May), wet and warm rainy (June to October), and dry and cool winter (November to February). The mean monthly minimum and maximum air temperature during 2005-2014 ranged from $10.9{ }^{\circ} \mathrm{C}$ to $25.3^{\circ} \mathrm{C}$ and $22.6{ }^{\circ} \mathrm{C}$ to $33.2{ }^{\circ} \mathrm{C}$, respectively. The average annual rainfall for the period was $1998.6 \mathrm{~mm}$ (Fig. 2). Relative humidity was higher in rainy season with highest value in August (92\%).

The forest is bordered by the Siwalik hill in the north and the Gangetic alluvial plains in the south. The area has been formed from soft erodible sediments of the Siwaliks and is characterized by the presence of boulder beds mixed with sand, silt, clay imparting a porous nature. The soil mainly consists of deep alfisols.

The forest tree layer is dominated by Sal. Other main associates are Haldina cordifolia, Lagerstroemia parviflora, and Terminalia alata. Clerodendron viscosum and Murraya koenigii are some of the main shrub species while Chromolaena odorata and Achyranthes aspera are dominant herbs.

\section{Plant biomass estimation}

The forest was divided into 2 parts: i) the relatively undisturbed core area (treated as undisturbed stand; US), and ii) the disturbed peripheral area (treated as disturbed stand; DS). Because of the following characters the core area was considered as US: canopy area ranged between 153.8 and $226.9 \mathrm{~m}^{2}$, crown cover ranged from $70-80 \%$, density of the tree was 466.4 individuals ha $^{-1}$ and tree stumps were absent. The peripheral part of the forest is disturbed because of following characters: canopy area ranged between 28.3 and $77.5 \mathrm{~m}^{2}$, crown cover ranged from $30-40 \%$, tree density was 234.3 individuals $\cdot \mathrm{ha}^{-1}$ and tree stump density was 70 stumps $\cdot \mathrm{ha}^{-1}$.

The tree biomass contained within US was estimated using 35 randomly established sample plots of $20 \mathrm{~m} \times 20 \mathrm{~m}$ size determined by species-area curve method. Same size was applied for DS as well. For the estimation of shrub and herb biomass nested quadrats of $5 \mathrm{~m} \times 5 \mathrm{~m}$ and $1 \mathrm{~m} \times 1 \mathrm{~m}$ were used, respectively. Girths of all the trees $(>10 \mathrm{~cm}$ gbh $)$ at breast height $(1.37 \mathrm{~cm}$ above the soil) and of shrubs $(10 \mathrm{~cm}$ above the ground level) present in each of the sample plots were measured. Density (individual per hectare) and basal area $\left(\operatorname{girth}^{2} \cdot(4 \pi)^{-1}\right)$ of the trees within plots were determined. Biomass of trees was estimated by using girth:biomass allometric equations (Singh and Singh 1992; Mandal 1999). For estimating coarse root biomass, root:shoot ratio of 0.21 proposed for lowland tropical forests was used (Malhi et al. 2009; Malhi et al. 2014).

The aboveground herbaceous biomass present in the sampling plots was harvested twice, in summer (May 2012) and at the end of rainy season (September 2012). Summer and rainy season values were averaged to obtain annual mean herbaceous biomass.

Fine roots $(<5 \mathrm{~mm}$ diameter) were collected from seventy randomly established sample plots, thirty five each in US and DS. Fine root biomass (FRB) was determined from soil monolith $(10 \mathrm{~cm} \times 10 \mathrm{~cm} \times$ $30 \mathrm{~cm}$ ), divided into two depth ranges (upper: 0$15 \mathrm{~cm}$ and lower: 15-30 cm) at each sample plot in summer (May 2011), rainy (September 2011) and 


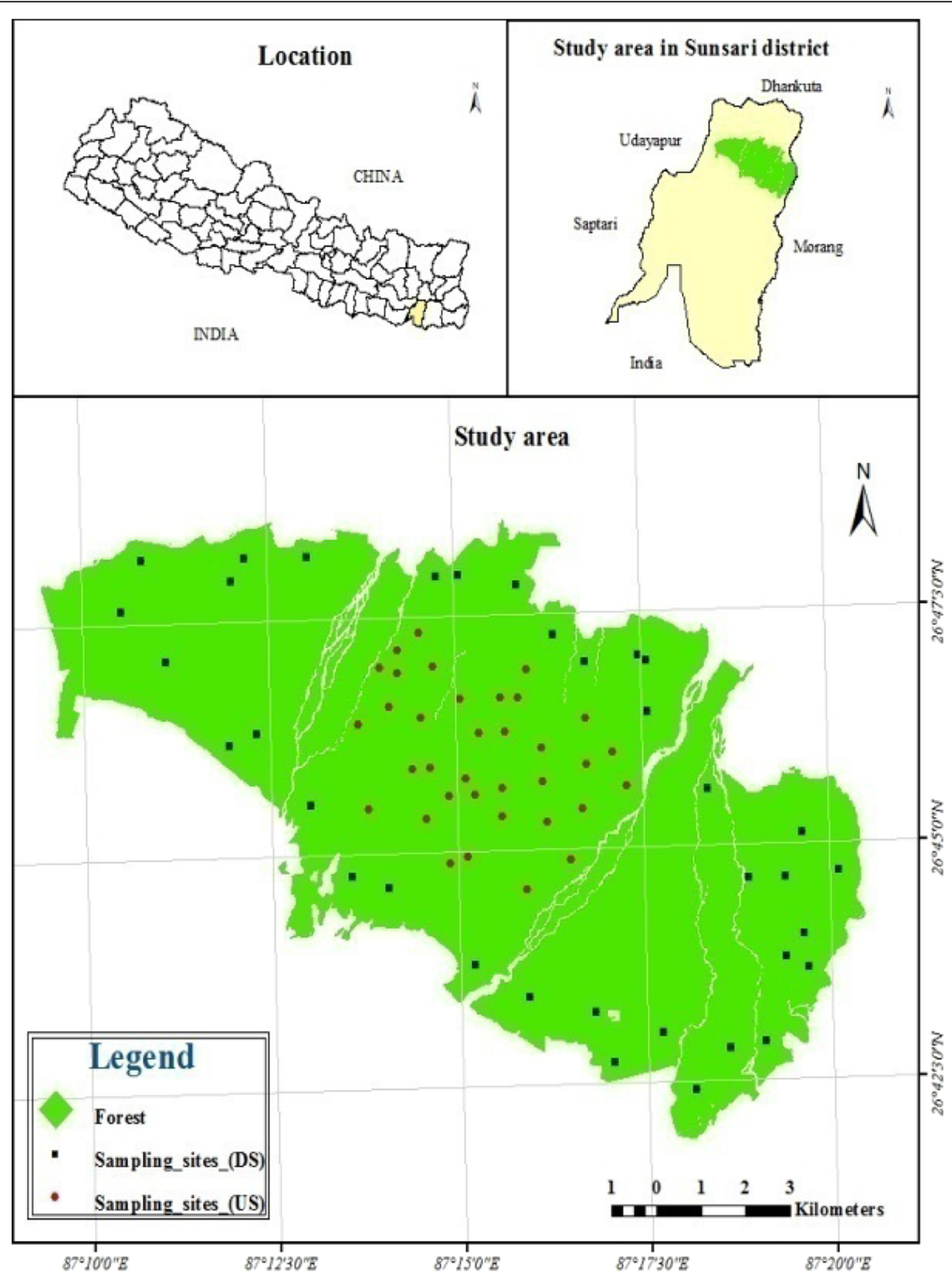

Fig. 1 Location of the study forest in eastern Nepal and the sample plots

winter (January 2012) seasons. Summer, rainy and winter season values were averaged to obtain annual mean FRB.

\section{Litterfall and litter mass}

For the estimation of litterfall one litter trap ( $1 \mathrm{~m} \times$ $1 \mathrm{~m})$ was fixed on the forest floor at each of the seventy sampling plots. Litterfall was collected at monthly intervals from April 2011 to March 2012 and categorized into leaf and non-leaf components. Litter mass accumulated at each sampling plot was collected once every season from one $1 \mathrm{~m} \times 1 \mathrm{~m}$ plot.
The turnover rate of litter was calculated according to Jenny et al. (1949).

\section{Net production}

Using the allometric equations, the aboveground biomass (AGB) of different components of marked trees/shrubs in permanent sampling plots was computed for $2011\left(B_{1}\right)$ and $2012\left(B_{2}\right)$ from respective girth measurements. The net changes in biomass $\left(\Delta B=B_{2}-B_{1}\right)$ of components yielded annual biomass increments which were summed to get the net AGB accretion in the trees/shrubs. Aboveground herbaceous net production was estimated as the 


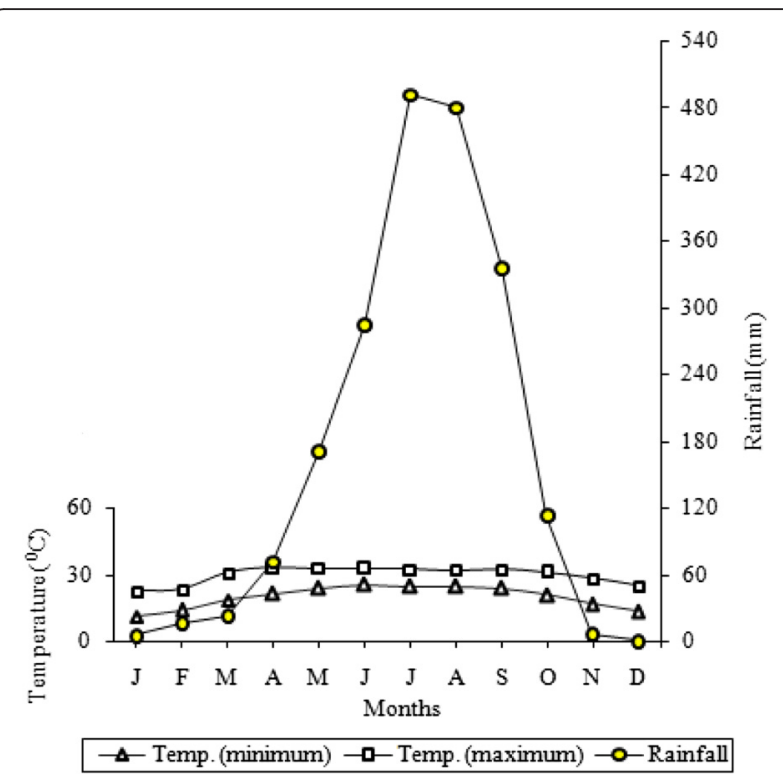

Fig. 2 Ombrothermic representation of the climate in tropical moist forest region of eastern Nepal. The data pertain to the period 2005-2014

differences between maximum and minimum biomass values through the year.

The annual leaf fall was added to the foliage biomass accumulation to represent leaf production, and wood and miscellaneous litterfall values were added to the biomass accumulation in twigs (Singh et al. 1994). Coarse root production was estimated as a fraction of stem production (Malhi et al. 2009; Malhi et al. 2014). Fine root production (FRP) was estimated as the differences between maximum (rainy season values) and minimum (summer season values) biomass values. The fine root turnover was calculated as a ratio of its production and annual mean biomass (Srivastava et al. 1986).

\section{Carbon estimation in vegetation and litter}

Samples of different tree, shrub and herb (aboveground) components of all species were collected from each sampling plot. The litter (leaf and nonleaf) and fine root ( $<2$ and $2-5 \mathrm{~mm}$ diameter) samples were also collected. All the samples were oven dried at $80{ }^{\circ} \mathrm{C}$ to constant weight, powdered and used separately for $\mathrm{C}$ analyses.

Carbon present in plant materials was estimated by ash content method. Carbon concentrations were assumed to be approximately $50 \%$ of ash free weight (McBrayer and Cromack 1980). In this method oven dried plant components (stem, branch, root, leaf, and litter) were burnt separately in electric furnace at $400{ }^{\circ} \mathrm{C}$. Ash content (inorganic elements in the form of oxides) left after burning was weighed and carbon concentration was calculated by using the following equation:

$$
\begin{aligned}
\% \text { Carbon }= & (\text { Initial weight }- \text { Ash weight }) \\
& \times 100 / 2
\end{aligned}
$$

The $\mathrm{C}$ stock in vegetation was calculated by multiplying $\mathrm{C}$ concentration (a conversion factor) to dry weight. A conversion factor of 0.470 was used to convert aboveground and coarse root biomass to $\mathrm{C}$. To obtain $\mathrm{C}$ stock in fine roots a conversion factor of 0.430 and 0.455 was used for $<2$ and $2-5 \mathrm{~mm}$ size class, respectively. The conversion factors of 0.453 and 0.468 were used for leaf and non-leaf litter, respectively.

\section{Soil sampling and carbon estimation}

Soil samples were collected from 70 randomly selected pots (35 each in US and DS). Soil was collected from three pits $(10 \mathrm{~cm} \times 10 \mathrm{~cm} \times 30 \mathrm{~cm}$ each) from each plot. The soils of three pits were mixed and pooled as one replicate (Singh et al. 2001). Bulk density (BD) was determined by using a metallic tube while soil organic carbon (SOC) by dichromate oxidation method (Kalembasa and Jenkinson 1973). Carbon content in soil ( $\mathrm{Mg} \mathrm{C} \cdot \mathrm{ha}^{-1}$ soil) was calculated using the formula:

$$
\mathrm{C}=\mathrm{SOC} \times \text { soil depth } \times \mathrm{BD}
$$

where SOC is soil organic carbon in \% and BD is bulk density $\left(\mathrm{g} \cdot \mathrm{cm}^{-3}\right)$.

\section{Statistical analysis}

Statistical tests were carried out in MS excel 2007 and SPSS (IBM Statistics, ver. 20) packages. All the data were normally distributed except that of basal area of trees which were log transformed before analysis. Pearson's correlation coefficients were obtained between normal and linear data of biomass, net production, stand density and basal area of trees. Students $T$-test was performed to compare the mean biomass and production of trees between US and DS.

\section{Results}

\section{Plant biomass}

The biomass and $\mathrm{C}$ stocks of trees, shrubs, herbs and fine roots are summarized in Tables 1 and 2 . The estimated total biomass for the US was $960.4 \mathrm{Mg} \cdot \mathrm{ha}^{-1}$ (equivalent to $452.06 \mathrm{Mg} \mathrm{C} \cdot \mathrm{ha}^{-1}$ ), while for DS it was $449.1 \mathrm{Mg} \cdot \mathrm{ha}^{-1}$ (equivalent to $211.33 \mathrm{Mg} \mathrm{C} \cdot \mathrm{ha}^{-1}$ ).

The total biomass $\left(\mathrm{Mg} \cdot \mathrm{ha}^{-1}\right)$ of the tree layer in US and DS was found to be 948.0 and 438.4, respectively. The tree biomass in the US and DS was significantly different $(P<0.001$ at $95 \%$ confidence level). Of the total tree biomass, $83 \%$ was aboveground and $17 \%$ belowground 


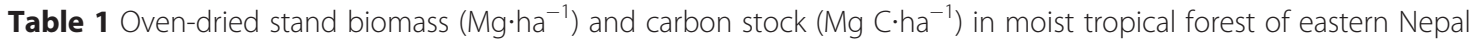

\begin{tabular}{|c|c|c|c|c|c|}
\hline \multicolumn{2}{|c|}{ Components } & \multicolumn{2}{|c|}{ Undisturbed stand } & \multicolumn{2}{|c|}{ Disturbed stand } \\
\hline & & \multirow{2}{*}{$\begin{array}{l}\text { Biomass } \\
610.4 \pm 20.0\end{array}$} & \multirow{2}{*}{$\begin{array}{l}\text { Carbon stock } \\
287.5\end{array}$} & \multirow{2}{*}{$\begin{array}{l}\text { Biomass } \\
281.5 \pm 15.8\end{array}$} & \multirow{2}{*}{$\begin{array}{l}\text { Carbon stock } \\
132.59\end{array}$} \\
\hline Trees & Bole & & & & \\
\hline & Branch & $119.4 \pm 3.2$ & 56.23 & $56.8 \pm 3.1$ & 26.75 \\
\hline & Twig & $32.9 \pm 1.6$ & 15.59 & $14.5 \pm 0.9$ & 6.87 \\
\hline & Leaf & $20.8 \pm 0.8$ & 9.67 & $9.5 \pm 0.5$ & 4.42 \\
\hline & Coarse root & $164.5 \pm 12.0$ & 77.48 & $76.1 \pm 11.0$ & 35.84 \\
\hline & Total & $948.0 \pm 108.8$ & 446.47 & $438.4 \pm 50.1$ & 206.47 \\
\hline \multirow[t]{4}{*}{ Shrubs } & Stem & $2.0 \pm 0.2$ & 0.94 & $3.00 \pm 0.4$ & 1.41 \\
\hline & Leaf & $1.0 \pm 0.1$ & 0.46 & $1.14 \pm 0.1$ & 0.52 \\
\hline & Root & $1.4 \pm 0.1$ & 0.66 & $1.92 \pm 0.2$ & 0.90 \\
\hline & Total & $4.4 \pm 0.3$ & 2.06 & $6.1 \pm 0.5$ & 2.83 \\
\hline \multicolumn{2}{|l|}{ Herbs $^{\mathrm{a}}$} & $1.4 \pm 0.1$ & 0.61 & $1.2 \pm 0.1$ & 0.53 \\
\hline \multicolumn{2}{|c|}{ Stand fine root } & $6.6 \pm 0.1$ & 2.92 & $3.4 \pm 0.2$ & 1.50 \\
\hline \multicolumn{2}{|c|}{ Total, Vegetation } & $960.4 \pm 73.1$ & 452.06 & $449.1 \pm 33.6$ & 211.33 \\
\hline
\end{tabular}

${ }^{a}$ Aboveground parts

(excluding fine root) in both the stands. The maximum contribution to tree AGB was made by bole in both stands (64 \% each) and minimum by foliage (2\% each in both stands).

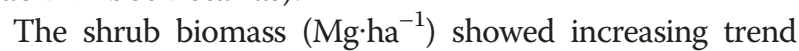
from 4.4 at US to 6.1 at DS. Contribution of shrub biomass to the total stand biomass was higher in DS (1.4 \%) than US (0.5\%). The aboveground herbaceous biomass contributed $0.1 \%$ in US and $0.3 \%$ in DS. The fine roots shared $0.7-0.8 \%$ to total stand biomass. The annual FRB was lower in DS by $49.5 \%$.

\section{Litterfall}

The total annual litterfall $\left(\mathrm{Mg} \cdot \mathrm{ha}^{-1} \cdot \mathrm{yr}^{-1}\right)$ was 11.8 in US and 5.4 in DS. Leaves accounted for $69 \%$ (US) to $76 \%$ (DS) of total litterfall while non-leaf litter formed the rest. The total litter mass $\left(\mathrm{Mg} \cdot \mathrm{ha}^{-1}\right)$ comprised 6.7 in US and 3.6 in DS. The turnover rate (per yr) of the total litter ranged from 0.79 in DS to 0.83 in US.

\section{Net production}

The total NPP $\left(\mathrm{Mg} \cdot \mathrm{ha}^{-1} \cdot \mathrm{yr}^{-1}\right)$ of the forest was 26.6 (equivalent to an annual $\mathrm{C}$ sequestration of $12.26 \mathrm{Mg}$
$\mathrm{C} \cdot \mathrm{ha}^{-1} \cdot \mathrm{yr}^{-1}$ ) in US and 14.9 (i.e. $6.88 \mathrm{Mg} \mathrm{C} \cdot \mathrm{ha}^{-1} \cdot \mathrm{yr}^{-1}$ ) in DS (Table 3). Among the different life forms: tree, shrub, and herb comprised $72 \%, 2 \%$, and $6 \%$ of NPP in US and $67 \%, 5 \%$, and $9 \%$ in DS, respectively; while rest $20 \%$ NPP in US and $19 \%$ in DS were contributed by stand fine root.

The contribution in NPP by different components of trees was in the order leaf $>$ bole $>$ twig $>$ coarse root $>$ branch, in both stands (Table 4). The most prominent $\mathrm{C}$ sink was found to be leaf that accounted for $42-43 \%$ of the total NPP. For shrub, maximum contribution to NPP was made by stem in both stands and minimum by foliage. The NPP of herbs (aboveground) ranged between 1.3 and $1.7 \mathrm{Mg} \cdot \mathrm{ha}^{-1} \cdot \mathrm{yr}^{-1}$ in DS and US, respectively (Table 3).

Total aboveground NPP $\left(\mathrm{Mg} \cdot \mathrm{ha}^{-1} \cdot \mathrm{yr}^{-1}\right)$ combining tree, shrub and herb were 19.93 in US and 10.97 in DS. In belowground parts, percentage allocation of NPP was up to $25 \%$ of total NPP (26.58 Mg.ha $\left.{ }^{-1} \cdot \mathrm{yr}^{-1}\right)$ in US and $26 \%\left(3.94 \mathrm{Mg} \cdot \mathrm{ha}^{-1} \cdot \mathrm{yr}^{-1}\right)$ in DS (Table 5). Of this, both tree and shrub's coarse root contributed about 21 and $26 \%$ to total belowground NPP in US and DS, respectively; whereas fine root comprised nearly $79 \%$ of belowground NPP in US and $74 \%$ in DS.

Table 2 Carbon stock (Mg C.ha ${ }^{-1}$ ) estimates for undisturbed and disturbed stands of moist tropical forest of eastern Nepal

\begin{tabular}{|c|c|c|c|c|}
\hline \multirow[t]{2}{*}{ Component } & \multicolumn{2}{|c|}{ Undisturbed stand } & \multicolumn{2}{|c|}{ Disturbed stand } \\
\hline & Carbon stocks & $\%$ of total & Carbon stocks & $\%$ of total \\
\hline Aboveground biomass & 371.0 & 68.7 & 173.1 & 64.0 \\
\hline Coarse roots & 78.1 & 14.5 & 36.7 & 13.6 \\
\hline Fine roots & 2.9 & 0.5 & 1.5 & 0.5 \\
\hline Soil (to $30 \mathrm{~cm}$ depth) & 88.1 & 16.3 & 59.3 & 21.9 \\
\hline Total & 540.2 & 100 & 270.6 & 100 \\
\hline
\end{tabular}


Table 3 Net primary production (NPP; Mg $\left.\cdot \mathrm{ha}^{-1} \cdot \mathrm{yr}^{-1}\right)$ and carbon allocation $\left(\mathrm{Mg} \mathrm{C} \cdot \mathrm{ha}^{-1} \cdot \mathrm{yr}^{-1}\right)$ in different components of vegetation in moist tropical forest of eastern Nepal

\begin{tabular}{|c|c|c|c|c|c|}
\hline \multicolumn{2}{|c|}{ Components } & \multicolumn{2}{|c|}{ Undisturbed stand } & \multicolumn{2}{|c|}{ Disturbed stand } \\
\hline & & \multirow{2}{*}{$\begin{array}{l}\mathrm{NPP} \\
4.78 \pm 0.25\end{array}$} & \multirow{2}{*}{$\frac{\text { Carbon allocation }}{2.25}$} & \multirow{2}{*}{$\frac{N P P}{2.96 \pm 0.16}$} & \multirow{2}{*}{$\frac{\text { Carbon allocation }}{1.39}$} \\
\hline Trees & Bole & & & & \\
\hline & Branch & $0.91 \pm 0.05$ & 0.43 & $0.57 \pm 0.03$ & 0.27 \\
\hline & Twig & $3.93 \pm 0.02$ & 1.86 & $1.45 \pm 0.01$ & 0.69 \\
\hline & Leaf & $8.24 \pm 0.01$ & 3.83 & $4.19 \pm 0.01$ & 1.95 \\
\hline & Coarse root & $1.27 \pm 0.02$ & 0.60 & $0.79 \pm 0.06$ & 0.37 \\
\hline & Total & $19.13 \pm 1.21$ & 8.97 & $9.96 \pm 0.75$ & 4.67 \\
\hline \multirow[t]{4}{*}{ Shrubs } & Stem & $0.30 \pm 0.03$ & 0.14 & $0.42 \pm 0.04$ & 0.20 \\
\hline & Leaf & $0.07 \pm 0.04$ & 0.03 & $0.08 \pm 0.01$ & 0.04 \\
\hline & Root & $0.18 \pm 0.02$ & 0.08 & $0.25 \pm 0.02$ & 0.12 \\
\hline & Total & $0.55 \pm 0.07$ & 0.25 & $0.75 \pm 0.10$ & 0.36 \\
\hline \multicolumn{2}{|l|}{ Herbs $^{a}$} & $1.70 \pm 0.12$ & 0.74 & $1.30 \pm 0.09$ & 0.57 \\
\hline \multicolumn{2}{|c|}{ Stand fine root } & $5.20 \pm 0.21$ & 2.30 & $2.90 \pm 0.16$ & 1.28 \\
\hline \multicolumn{2}{|c|}{ Total, Vegetation } & $26.58 \pm 0.87$ & 12.26 & $14.91 \pm 0.44$ & 6.88 \\
\hline \multicolumn{2}{|l|}{${ }^{\mathrm{b}} \mathrm{BAR}$} & \multicolumn{2}{|l|}{36} & \multicolumn{2}{|l|}{30} \\
\hline
\end{tabular}

${ }^{\text {aAboveground parts }}$

${ }^{\mathrm{b}}$ BAR: Biomass accumulation ratio (biomass/annual net production)

Considering both depths, average turnover rate (per yr) of smaller fine roots $(0-2 \mathrm{~mm}$ diameter) was 0.75 in US and 0.86 in DS, whereas it was 0.74 and 0.76 for larger size class $(2-5 \mathrm{~mm})$ in US and DS, respectively. The biomass accumulation ratio (biomass/net production) decreased to 30 due to the consequences of forest disturbance in DS, while this value was higher (36) in US. Net production of trees was significantly higher in US than DS $(P<0.001)$. Positive correlations were found between stand density, basal area, biomass and NPP of trees in both stands (Table 5).

Table 4 Net production $\left(\mathrm{Mg} \cdot \mathrm{ha}^{-1} \cdot \mathrm{yr}^{-1}\right)$ of trees and shrubs and their distribution (\%) in different components in moist tropical forest of eastern Nepal

\begin{tabular}{lll}
\hline Components & Forest stands \\
\cline { 2 - 3 } & Undisturbed & Disturbed \\
\hline Trees & $19.13 \pm 1.21$ & $9.96 \pm 0.75$ \\
Bole (\%) & 25 & 30 \\
Branch (\%) & 5 & 6 \\
Twig (\%) & 20 & 14 \\
Leaf (\%) & 43 & 42 \\
Coarse root (\%) & 7 & 8 \\
Shrubs & $0.55 \pm 0.07$ & $0.75 \pm 0.10$ \\
Stem (\%) & 54 & 56 \\
Leaf (\%) & 13 & 11 \\
Root (\%) & 33 & 33 \\
\hline
\end{tabular}

\section{Carbon budget and flux}

The dry matter values for standing crops, net production, litterfall etc. of both undisturbed and disturbed stands were converted to C (Figs. 3 and 4). Aboveground $C$ storage in both stands was $82 \%$ of the total $C$ in vegetation and 64-69\% of that stored in stand (vegetation plus soil). The forest received a C input through NPP of $12.26 \mathrm{Mg} \cdot \mathrm{ha}^{-1} \cdot \mathrm{yr}^{-1}$ in US and $6.88 \mathrm{Mg} \cdot \mathrm{ha}^{-1} \cdot \mathrm{yr}^{-1}$ in DS. Of this, $69 \%$ was associated with aboveground and $31 \%$ with root NPP in US while in DS, contributions from aboveground and root parts to total NPP was 67 and $33 \%$, respectively.

Wood (bole plus branch) and roots accounted for $47 \%$ (in US) to $53 \%$ (in DS) of the total C input, the remaining $53 \%$ in US and $47 \%$ in DS being utilized for

Table 5 Pearson's correlations between stand density, basal area, biomass and net production of trees in undisturbed and disturbed stands of moist tropical forest in eastern Nepal

\begin{tabular}{llll}
\hline & Density & Basal area & Biomass \\
\hline Undisturbed stand & & & \\
Basal area & 0.293 & & \\
Biomass & 0.251 & $0.902^{\mathrm{b}}$ & 0.279 \\
Net production & $0.725^{\mathrm{b}}$ & 0.210 & \\
Disturbed stand & & & \\
Basal area & 0.116 & & \\
Biomass & 0.221 & $0.926^{\mathrm{b}}$ & $0.525^{\mathrm{b}}$ \\
Net production & $0.788^{\mathrm{b}}$ & $0.347^{\mathrm{a}}$ &
\end{tabular}

${ }^{\mathrm{b}}$ Correlation is significant at the 0.01 level (2-tailed) and ${ }^{\mathrm{a}}$ at the 0.05 level (2-tailed) 


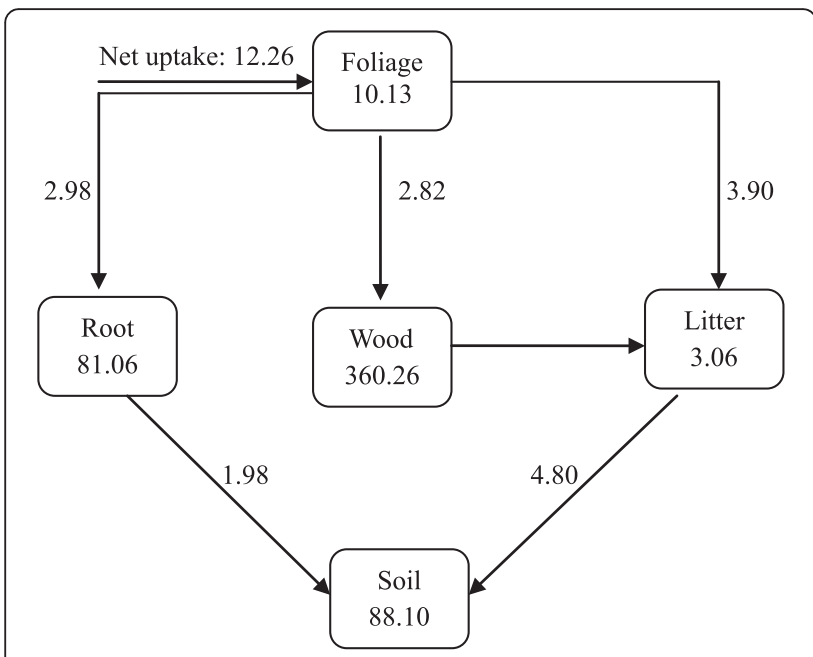

Fig. 3 Compartment model showing annual carbon budget for the undisturbed stand of the moist tropical forest of eastern Nepal. Values in 'tanks' represent average carbon content $\left(\mathrm{Mg} \cdot \mathrm{ha}^{-1}\right)$. The foliage compartment also includes aboveground standing crop of herbs, and the root compartment includes coarse roots as well as fine roots. Net annual fluxes between the compartments are given on arrows $\left(\mathrm{Mg}_{\mathrm{ha}} \mathrm{har}^{-1} \cdot \mathrm{yr}^{-1}\right)$

the extension of the photosynthetic parts (tree and shrub foliage plus herbaceous shoots). The input from the foliage compartment to the litter compartment was $3.90 \mathrm{Mg} \cdot \mathrm{ha}^{-1} \cdot \mathrm{yr}^{-1}$ (equivalent to $100 \%$ of herbaceous aboveground production plus $86 \%$ of foliage production) in US while it was $2.17 \mathrm{Mg} \cdot \mathrm{ha}^{-1} \cdot \mathrm{yr}^{-1}$ for DS. About $14 \%$ $\left(0.51 \mathrm{Mg} \cdot \mathrm{ha}^{-1} \cdot \mathrm{yr}^{-1}\right.$ in US and $0.26 \mathrm{Mg} \cdot \mathrm{ha}^{-1} \cdot \mathrm{yr}^{-1}$ in DS) of foliage production did not find its way into leaf litterfall.

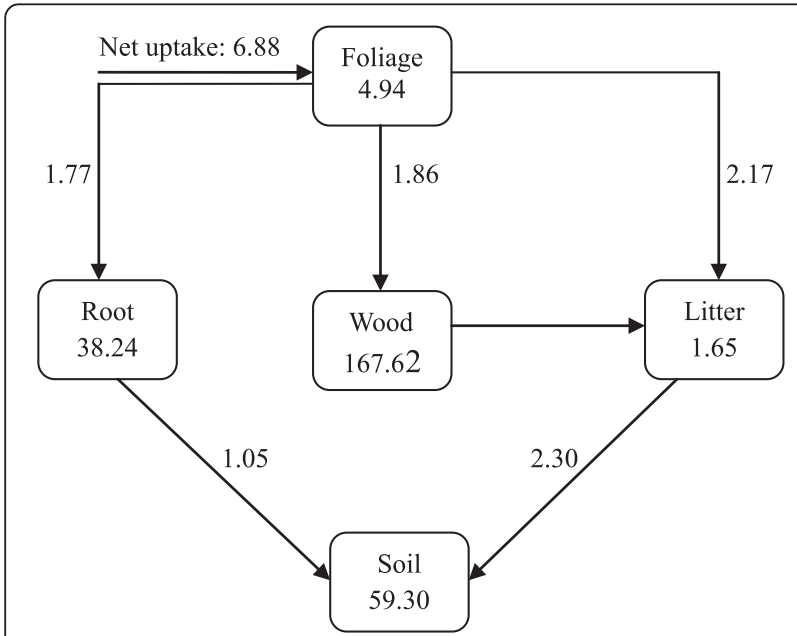

Fig. 4 Compartment model showing annual carbon budget for the disturbed stand of the moist tropical forest of eastern Nepal. Values in 'tanks' represent average carbon content $\left(\mathrm{Mg} \cdot \mathrm{ha}^{-1}\right)$. The foliage compartment also includes aboveground standing crop of herbs, and the root compartment includes coarse roots as well as fine roots. Net annual fluxes between the compartments are given on arrows (Mg ha $^{-1} \cdot \mathrm{yr}^{-1}$ )
Carbon addition to the soil through the turnover of roots and aboveground litter amounted to 1.98 and $4.80 \mathrm{Mg} \cdot \mathrm{ha}^{-1} \cdot \mathrm{yr}^{-1}$, respectively in US (fine root and litter turnover were 86 and $83 \%$ per yr, respectively). Similarly, $C$ input due to the turnover of roots and aboveground litter was 1.05 and $2.30 \mathrm{Mg} \cdot \mathrm{ha}^{-1} \cdot \mathrm{yr}^{-1}$, respectively in DS (fine root and litter turnover were 82 and $79 \%$ per yr, respectively). Evidently, contribution of belowground plant parts to soil $\mathrm{C}$ is substantial, representing 29 and $32 \%$ of the total input in US and DS, respectively.

\section{Discussion}

\section{Biomass and production}

The average biomass of the vegetation in both US and DS

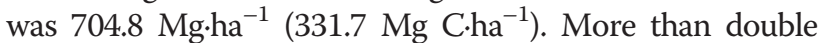
biomass in US as compared to DS may be related to the presence of more trees of larger girth classes. The lower biomass in DS may be the result of lower density of trees (234 individuals $\cdot \mathrm{ha}^{-1}$ ) compared to US (466 individuals.ha ${ }^{-}$ $\left.{ }^{1}\right)$. It may also be associated with disturbance activities like tree felling and removing for timber, firewood collection, lopping, grazing, and selective logging.

Biomass allocated to shrub was higher in DS than US. It may be the result of their ability to utilize the space and resource created by disturbances. The higher biomass of herbs in US as compared to DS may be due to the nutrient rich soil at this stand (Gautam and Mandal 2013). The different causes are put forward by different workers regarding the accumulation of biomass in the forest. Mean annual precipitation explains $55 \%$ of the variation in biomass in seasonally dry tropical forests (Becknell et al. 2012). The available nutrients, soil, land use history, species composition and stand age are also responsible for the remaining variations (Powers et al. 2009).

Most of the $\mathrm{C}$ stock in the forest was associated with AGB (64-69 \%). Belowground biomass and soil up to the depth of $30 \mathrm{~cm}$ contained 31 to $36 \%$ C stock. Past study also found $33 \% \mathrm{C}$ in top soil of $1 \mathrm{~m}$ in primary tropical forest of Singapore (Ngo et al. 2013). Globally, tropical forests store about $50 \% \mathrm{C}$ in AGB and next $50 \%$ within $1 \mathrm{~m}$ soil (Dixon et al. 1994). The contribution of these pools to the total $\mathrm{C}$ stocks varies among the sites. For example, an African moist tropical forest had more than three times as much $C$ in AGB as in soil to $1 \mathrm{~m}$ depth (Djomo et al. 2011), while a Peruvian montane forest had twice as much $\mathrm{C}$ in soil as in AGB (Gibbon et al. 2010). Two Asian forests, a tropical seasonal forest in China (Lü et al. 2010) and a lowland dipterocarp forest in Malaysia (Saner et al. 2012) store twice as much $\mathrm{C}$ in biomass as in soil. The contribution of leaf fall to total litterfall in the present study (69\% at US and $76 \%$ at DS) is in the range of past studies in tropical forests (72-74 \%) (Girardin et al. 2014; Malhi et al. 2014). 
The data obtained for NPP are comparable with the different tropical forests of world (Table 6). Although having higher biomass, the NPP of present forest is relatively low indicating its maturity. Generally, in old growth tropical forests the NPP remains either stationary or decreases with age. The higher NPP of some old tropical forests may be linked to forest dynamics. The more dynamic forests favor faster growing trees and species with lower biomass and maintenance costs (Malhi et al. 2009).

Aboveground NPP of US (8.54 Mg C.ha ${ }^{-1} \cdot \mathrm{yr}^{-1}$, excluding herbs) is comparable with the tropical forests of world while quite low than the eastern Amazonian forest (Doughty et al. 2013). Moreover, aboveground NPP of DS (4.54 Mg C.ha ${ }^{-1} \cdot \mathrm{yr}^{-1}$, excluding herb) is near to paleotropical forests, and mean of the world tropical forests. As far as the belowground NPP is concerned (1.77-2.98 Mg C.ha $\left.{ }^{-1} \cdot \mathrm{yr}^{-1}\right)$, it is comparable to the Amazonian tropical forest (Table 6).

Disturbance affects the NPP either by increasing resource availability or through the changes in functional properties of community. The disturbance results in canopy opening, which increases availability of light, favor new leaf production, and finally above-ground allocation increases (Aragão et al. 2009). But in the present study, percentage allocation to aboveground parts was almost same in both US and DS. It may be the result of severe lopping activities in DS, which is also indicated by less percentage of NPP allocation to twig and leaf, and higher percentage allocation to bole and branch in DS. Relatively higher percentage of NPP in coarse root of DS indicated higher allocation to root to collect more water and nutrients from nutrient deficient soil.

Among different components of trees, leaf accounted highest percentage (43\% in US and $42 \%$ in DS) of tree NPP. It was almost similar to the earlier findings for tropical forests (Hertel et al. 2009; Doughty et al. 2013). A global dataset of NPP allocation in tropical forests reported $34 \%$ in canopy, $39 \%$ in wood, and $27 \%$ in fine roots (Malhi et al. 2011). Present data of US, excluding herb NPP, also showed almost same pattern of allocation
(33\% canopy, $46 \%$ woody tissue including coarse root, and $21 \%$ fine roots).

Higher allocation of NPP in shrubs of DS as compared to that of US may be due to open canopy created as a result of logging and lopping of trees. The higher NPP of herbs in US might be associated with higher moisture and nutrients due to accumulation of more litter on the soil. Fine root, although sharing a very small percentage to total plant biomass, is one of the major belowground components of the NPP. In present study, FRB shared less than $1 \%$ to total biomass but contributed 19-20\% to total NPP. The estimated FRP in this study was within the ranges of $1.1-6.2 \mathrm{Mg} \cdot \mathrm{ha}^{-1} \cdot \mathrm{yr}^{-1}$ for global tropical forests (Vogt et al. 1986).

\section{Carbon budget and flux}

Aboveground $\mathrm{C}$ storage in both stands was $82 \%$ of the total stored in vegetation and 64-69 \% of that stored in the stand (vegetation plus soil). These values compare with the aboveground storage of $83 \%$ vegetation $\mathrm{C}$ and $51 \%$ stand $\mathrm{C}$ in a dry tropical forest in India (Singh and Singh 1991). As in other tropical forests, relatively higher contribution of aboveground parts to the stand $C$ in present case may be due to the presence of large sized trees with wide canopy.

The contribution of aboveground (74-75\%) and root (25-26\%) parts to stand NPP in both forest stands is comparable to $72 \%$ NPP for aboveground parts (Singh and Singh 1991). The higher contribution of wood parts to the total $\mathrm{C}$ input as compared to foliage in DS may be due to the lopping of branches and twigs. On the other hand, closed canopy of trees in US accounted for higher input of foliage C compared to wood.

The transfer of $\mathrm{C}$ from foliage compartment to the litter compartment involved $100 \%$ of herbaceous aboveground production plus $86 \%$ of foliage production while the remaining amount, i.e., about $14 \%$ of foliage production did not find its way into leaf litterfall. It happens due to the losses during senescence (Singh and Singh 1991).

Table 6 Net primary production (NPP) of different forests of the World

\begin{tabular}{|c|c|c|c|c|}
\hline \multirow[t]{2}{*}{ Locality and forest types } & \multicolumn{3}{|c|}{$\operatorname{NPP}\left(\mathrm{Mg} \mathrm{C} \cdot \mathrm{ha}^{-1} \cdot \mathrm{yr}^{-1}\right)$} & \multirow[t]{2}{*}{ References } \\
\hline & Aboveground & Belowground & Total & \\
\hline Amazonia & - & - & $10.0-14.4$ & (Malhi et al. 2009) \\
\hline Peru (W. Amazonia) & - & - & $14.2-15.1$ & (Malhi et al. 2014) \\
\hline Global (Old tropical) & - & - & $3.1-21.7$ & (Chave et al. 2001) \\
\hline Central French Guiana (Lowland tropical rain) & 8.81 & - & - & (Chave et al. 2008) \\
\hline Africa (Tropical) & - & - & 11.51 & (Bombelli et al. 2009) \\
\hline Nepal (Moist tropical Plateau Sal) & 14.89 & 7.21 & $22.1 \pm 1.4$ & (Mandal 1999) \\
\hline Nepal (Moist tropical) & $10.97-19.93$ & $3.94-6.65$ & $14.91-26.58$ & Present study \\
\hline
\end{tabular}


Litterfall and FRB are important vectors of nutrient recycling in forest ecosystems. Their turnover is usually determined by species, age groups, canopy cover, weather conditions and biotic factors. Total $\mathrm{C}$ input into soil through litter plus root turnover was 6.78 and $3.35 \mathrm{Mg} \cdot \mathrm{ha}^{-1} \cdot \mathrm{yr}^{-1}$ in US and DS, respectively, suggesting substantial retention of $C$ in the vegetation over in annual cycle ( $45 \%$ in US and $51 \%$ in DS). It indicates that the present forest is $\mathrm{C}$-accumulating system, acting as a significant global $\mathrm{C}$ sink, as other wet tropical forests (Pan et al. 2011).

\section{Conclusions}

The present study indicated that various types of anthropogenic disturbances have altered the structure and functioning of the economically important Saldominated forest. Although in having higher biomass, the NPP of present forest is relatively low indicating its maturity. Several disturbance activities like lopping, fodder collection, litter removal, grazing etc. result in the significant loss in stand biomass (53\%) and net production (44\%). Due to forest disturbance $\mathrm{C}$ stock and $\mathrm{C}$ sequestration capacity are reduced which reflects the higher $C$ emissions. From the management point of view, better policy to reduce the $\mathrm{C}$ emission through vegetation should be formulated as per the objective of REDD ${ }^{+}$. In spite of this, both stands of this forest appear to act as Caccumulating system, an important global $\mathrm{C}$ sink.

\section{Abbreviations}

AGB: aboveground biomass; DS: disturbed forest stand; NPP: net primary production; US: undisturbed forest stand.

\section{Competing interests}

The authors declare that they have no competing interests.

\section{Authors' contributions}

TP carried out field and laboratory works, analyzed data, designed and drafted the manuscript. TN designed and supervised the research. Both authors read and approved the final manuscript.

\section{Authors' information}

1) TP participated in this research as a doctoral student. At present, he is working as Associate Professor in the Department of Botany, Mahendra Morang Adarsha Multiple Campus, Tribhuvan University, Biratnagar, Nepal. 2) TN is a professor of Botany in Post Graduate Campus, Tribhuvan University, Biratnagar, Nepal.

\section{Acknowledgements}

The authors are grateful to the Head, Department of Botany, Post Graduate Campus, Tribhuvan University, Biratnagar, Nepal for providing laboratory and library facilities. First author is thankful to the University Grants Commission, Nepal for Scholarship. Our heartfelt thanks go to Mr. KP Bhattarai who helped in data collection and laboratory analysis.

\section{Author details}

'Department of Botany, Mahendra Morang Adarsha Multiple Campus, Tribhuvan University, Biratnagar, Nepal. ${ }^{2}$ Department of Botany, Post Graduate Campus, Tribhuvan University, Biratnagar, Nepal.
Received: 10 February 2016 Accepted: 18 April 2016

Published online: 26 April 2016

\section{References}

Aragão LEOC, Malhi Y, Metcalfe DB, Silva-Espejo JE, Jiménez E, Navarrete D, Almeida S, Costa ACL, Salinas N, Phillips OL, Anderson LO, Alvarez E, Baker TR, Goncalvez PH, Huamán-Ovalle J, Mamani-Solórzano M, Meir P, Monteagudo A, Patiño S, Peñuela MC, Prieto A, Quesada CA, Rozas-Dávila A, Rudas A, Silva JA Jr, Vásquez R (2009) Above- and below-ground net primary productivity across ten Amazonian forests on contrasting soils. Biogeosciences 6:2759-2778

Baral SK, Malla R, Ranabhat S (2009) Above-ground carbon stock assessment in different forest types of Nepal. Banko Jankari 19:10-14

Becknell JM, Kissing Kucek L, Powers JS (2012) Aboveground biomass in mature and secondary seasonally dry tropical forests: A literature review and global synthesis. For Ecol Manag 276:88-95

Beer C, Reichstein M, Tomelleri E, Ciais P, Jung M, Carvalhais N, Rodenbeck C, Altaf Arain M, Baldocchi D, Bonan GB, Bondeau A, Cescatti A, Lasslop G, Lindroth A, Lomas M, Luyssaert S, Margolis H, Oleson KW, Roupsard O, Veenendaal E, Viovy N, Williams C, Woodward FI, Papale D (2010) Terrestrial gross carbon dioxide uptake: global distribution and covariation with climate. Science 329:834-838

Bombelli A, Henry M, Castaldi S, Adu-Bredu S, Arneth A, de Grandcourt A, Grieco E, Kutsch WL, Lehsten V, Rasile A, Reichstein M, Tansey K, Weber U, Valentini R (2009) The sub-Saharan Africa carbon balance, an overview. Biogeosci. Discuss 6:2085-2123.

Chave J, Olivier J, Bongers F, Châtelet P, Forget P-M, van der Meer P, Norden N, Riera B, Charles-Dominique $P$ (2008) Above-ground biomass and productivity in a rain forest of eastern South America. J Trop Ecol 24:355-366

Chave J, Riera B, Dubois MA (2001) Estimation of biomass in a Neotropical forest of French Guiana: Spatial and temporal variability. J Trop Ecol 17:79-96

Dixon RK, Solomon AM, Brown S, Houghton RA, Trexler MC, Wisniewski J (1994) Carbon pools and flux of global forest ecosystems. Science 263:185-190

Djomo AN, Knohl A, Gravenhorst G (2011) Estimations of total ecosystem carbon pools distribution and carbon biomass current annual increment of a moist tropical forest. For Ecol Manag 261:1448-1459

Doughty CE, Metcalfe DB, da Costa MC, de Oliveira AAR, Neto GFC, Silva JA, Aragão LEOC, Almeida SS, Quesada CA, Girardin CAJ, Halladay K, da Costa AC, Malhi Y (2013) The production, allocation and cycling of carbon in a forest on fertile terra preta soil in eastern Amazonia compared with a forest on adjacent infertile soil. Plant Ecol Diversity 7:41-53

Gautam TP, Mandal TN (2013) Soil characteristics in moist tropical forest of Sunsari district, Nepal. Nepal J Sci Tech 14:35-40

Gibbon A, Silman MR, Malhi Y, Fisher JB, Meir P, Zimmermann M, Dargie GC, Farfan WR, Garcia KC (2010) Ecosystem carbon storage across the grasslandforest transition in the high Andes of Manu National Park, Peru. Ecosystems 13:1097-1111

Girardin CAJ, Espejob JES, Doughty CE, Huasco WH, Metcalfe DB, Durand-Baca L, Marthews TR, Aragao LEOC, Farfán-Rios W, García-Cabrera K, Halladay K, Fisher JB, Galiano-Cabrera DF, Huaraca-Quispe LP, Alzamora-Taype I, EquiluzMora L, Salinas-Revilla N, Silman MR, Meir P, Malhi Y (2014) Productivity and carbon allocation in a tropical montane cloud forest in the Peruvian Andes. Plant Ecol Diversity 7:107-123

Hertel D, Moser G, Culmsee H, Erasmi S, Horna V, Schuldt B, Leuschner C (2009) Below- and above-ground biomass and net primary production in a paleotropical natural forest (Sulawesi, Indonesia) as compared to neotropical forests. For Ecol Manag 258:1904-1912

Ibrahima A, Mvondo ZEA, Ntonga JC (2010) Fine root production and distribution in the tropical rainforests of south-western Cameroon: effects of soil type and selective logging. iForest: Biogeosc For 3:130-136

Jenny H, Gessel SP, Bingham FT (1949) Comparative study of decomposition rates of organic matter in temperate and tropical region. Soil Sci 68:419-432

Kalembasa SJ, Jenkinson DS (1973) A comparative study of titremetric and gravimetric methods for the determination of organic carbon in soil. J Sci Food Agri 24:1085-1090

Lü XT, Yin JX, Jepsen MR, Tang JW (2010) Ecosystem carbon storage and partitioning in a tropical seasonal forest in Southwestern China. For Ecol Manag 260:1798-1803

Malhi Y, Aragao LEO, Metcalfe DLB, Paiva R, Quesada CA, Almeida S, Anderson L, Brando P, Chambers JQ, Costa ACL, Hutyra L, Oliveira P, Patino S, Pyle EH, Robertson AL, Teixeira LM (2009) Comprehensive assessment of carbon 
productivity, allocation and storage in three Amazonian forests. Glob Change Biol 15:1255-1274

Malhi Y, Doughty C, Galbraith D (2011) The allocation of ecosystem net primary productivity in tropical forests. Philos Trans R Soc B: Biol Sci 366:3225-3245

Malhi Y, Farfán Amézquita F, Doughty CE, Silva-Espejo JE, Girardin CAJ, Metcalfe DB, Aragão LEOC, Huaraca-Quispe LP, Alzamora-Taype I, Equiluz-Mora L, Marthews TR, Halladay K, Quesada CA, Robertson AL, Fisher JB, ZaragozaCastells J, Rojas-Villagra CM, Pelaez-Tapia Y, Salinas N, Meir P, Phillips OL (2014) The productivity, metabolism and carbon cycle of two lowland tropical forest plots in south-western Amazonia, Peru. Plant Ecol Diversity 7: 85-105

Mandal T (1999) Ecological analysis of recovery of landslide damaged Sal forest ecosystem in Nepal Himalaya. Dissertation, Banaras Hindu University, Varanasi

McBrayer JF, Cromack KJ (1980) Effect of snowpack on oak- litter breakdown and nutrient release in a Minnesota forest. Pedobiologia 20:47-54

Ngo KM, Turner BL, Muller-Landau HC, Davies SJ, Larjavaara M, Nik Hassan NF, Lum S (2013) Carbon stocks in primary and secondary tropical forests in Singapore. For Ecol Manag 296:81-89

Noguchi H, Suwa R, de Souza CAS, da Silva RP, dos Santos J, Higuchi N, Kajimoto T, Ishizuka M (2014) Examination of vertical distribution of fine root biomass in a tropical moist forest of the Central Amazon, Brazil. Japan Agri Res Quarterly 48:231-235

Pan Y, Birdsey RA, Fang J, Houghton R, Kauppi PE, Kurz WA, Phillips OL, Shvidenko A, Lewis SL, Canadell JG, Ciais P, Jackson RB, Pacala SW, McGuire AD, Piao S, Rautiainen A, Sitch S, Hayes D (2011) A large and persistent carbon sink in the world's forests. Science 333:988-993

Powers JS, Becknell JM, Irving J, Pèrez-Aviles D (2009) Diversity and structure of regenerating tropical dry forests in Costa Rica: Geographic patterns and environmental drivers. For Ecol Manag 258:959-970

Powers JS, Perez-Aviles D (2013) Edaphic factors are a more important control on surface fine roots than stand age in secondary tropical dry forests. Biotropica 45:1-9

Roderstein M, Hertel D, Leuschner C (2005) Above and below-ground litter production in three tropical montane forests in southern Ecuador. J Trop Ecol 21:483-492

Saner P, Loh YY, Ong RC, Hector A (2012) Carbon stocks and fluxes in tropical lowland dipterocarp rainforests in Sabah, Malaysian Borneo. PloS One 7. doi: 10.1371/journal.pone.0029642

Singh JS, Singh SP (1992) Forests of Himalaya. Gyanodaya Prakashan, Nainital

Singh KP, Mandal TN, Tripathi SK (2001) Patterns of restoration of soil physciochemical properties and microbial biomass in different landslide sites in the sal forest ecosystem of Nepal Himalaya. Ecol Eng 17:385-401

Singh L, Singh JS (1991) Storage and flux of nutrients in a dry tropical forest in India. Ann Botany 68:275-284

Singh SP, Adhikari BS, Zobel DB (1994) Biomass, productivity, leaf longevity, and forest structure in the Central Himalaya. Ecol Monogr 64:401-421

Srivastava SK, Singh KP, Upadhyay RS (1986) Fine root growth dynamics in teak (Tectona grandis Linn. F.). Can J For Res 16:1360-1364

Vogt KA, Grier CC, Vogt DJ (1986) Production, turnover and nutrient dynamics of above and belowground detritus of world forests. Adv Ecol Res 15:303-377

\section{Submit your manuscript to a SpringerOpen ${ }^{\circ}$ journal and benefit from:}

- Convenient online submission

- Rigorous peer review

- Immediate publication on acceptance

- Open access: articles freely available online

- High visibility within the field

- Retaining the copyright to your article 